\title{
ARTICLES
}

Submitted 05.08.2015. Approved 02.17.2016

Evaluated by double blind review process. Scientific Editor: Paulo Roberto Barbosa Lustosa

DOI: http://dx.doi.org/10.1590/So034-759020160307

\section{RISK DISCLOSURE ANALYSIS IN THE CORPORATE GOVERNANCE ANNUAL REPORT USING FUZZY-SET QUALITATIVE COMPARATIVE ANALYSIS}

\author{
Análise de divulgação de risco no Relatório Anual de Governança Corporativa \\ utilizando fuzzy-set qualitative comparative analysis
}

\section{Estudio de la divulgación de riesgos en el Informe Anual de Gobierno Corporativo mediante fuzzy-set qualitative comparative analysis}

\begin{abstract}
This paper explores the necessary and sufficient conditions of good Corporate Governance practices for high risk disclosure by firms in their Corporate Governance Annual Report. Additionally, we explore whether those recipes have changed during the financial crisis. With a sample of 271 Spanish listed companies, we applied fuzzy-set qualitative comparative analysis to a database of financial and non-financial data. We report that Board of Directors independence, size, level of activity and gender diversity, CEO duality, Audit Committee independence, being audited by the Big Four auditing firms and the presence of institutional investors are associated with high risk disclosure. The conditions included in almost every combination are the presence of institutional investors and being audited by the Big Four. We found similar combinations for 2006 and 2012, while the analysis for 2009 showed the lowest number of causal configurations.
\end{abstract}

KEYWORDS | Board composition, corporate governance, fuzzy-set qualitative comparative analysis, independent director, risk disclosure.

\section{RESUMO}

O presente artigo investiga as condições necessárias e suficientes das boas práticas de Governança Corporativa para a divulgação de alto risco, pelas empresas, no Relatório Anual de Governança Corporativa. Além disso, investigamos se tais fórmulas se alteraram durante a crise financeira. A partir de uma amostra de 271 empresas espanholas cotadas em bolsa, aplicamos uma análise comparativa qualitativa usando conjuntos Fuzzy a um banco de dados financeiros e não financeiros. Relatamos que a independência, tamanho, nível de atividade e diversidade de gênero do Conselho de Administração, a dualidade do Diretor Executivo, a independência do Comitê de Auditoria, o fato de estar sendo auditado pelas Big Four empresas de auditoria e a presença de investidores institucionais estão associados à divulgação de alto risco. As condições incluídas em quase todas as combinações são a presença de investidores institucionais e o fato de estar sendo auditado pelas Big Four. Encontramos combinações semelhantes para os anos de 2006 e 2012, enquanto a análise de 2009 apresentou o menor número de configurações causais.

\section{PEDRO CARMONA}

pedro.carmona@uv.es

Professor at Universitat de València, Departament de Comptabilitat -

València, Spain

\section{CRISTINA DE FUENTES}

cristina.de-fuentes@uv.es

Professor at Universitat de València,

Departament de Comptabilitat -

València, Spain

\section{CARMEN RUIZ}

caruizmo@alumni.uv.es

MsC in Auditing and Accounting from Universitat de València, Departament de Comptabilitat - València, Spain
PALAVRAS-CHAVE I Composição do Conselho de Administração, governança corporativa, análise comparativa qualitativa usando conjuntos fuzzy, diretor independente, divulgação de risco.

\section{RESUMEN}

Este trabajo analiza qué condiciones - relacionadas con las prácticas de buen gobierno corporativo-son necesarias y suficientes para que las empresas suministren alto contenido informativo sobre los riesgos en su Informe Anual de Gobierno Corporativo y si éstas condiciones han variado durante la crisis financiera. Para ello, sobre una muestra compuesta por 271 empresas españolas cotizadas se ha utilizado el fuzzy-set qualitative comparative analysis ( $\left.f_{S} Q C A\right)$. Los resultados muestran que la independencia, el tamaño, el nivel de actividad y la diversidad de género del Consejo de Administración, la dualidad del CEO, la independencia del Comité de Auditoría, estar auditada por una de las Big Four y la presencia de inversores institucionales están asociados con la elevada divulgación sobre riesgos. Casi todas las configuraciones incluyen la presencia de inversores institucionales y la auditoría por una de las Big Four. Por otro lado, se observan combinaciones de condiciones similares para los años 2006 y 2012, mientras que para el 2009 el número de configuraciones causales es menor.

PALABRAS CLAVE I Composición del Consejo de Administración, gobierno corporativo, fuzzy-set qualitative comparative analysis, comité de auditoría, divulgación de riesgos. 


\section{INTRODUCTION}

The main purpose of this work is to analyze whether different sets of mechanisms of good governance are associated with the level of firm risk disclosure in the Corporate Governance Annual Report (CGAR) and how these sets of mechanisms evolved during the period of financial crisis in Spain. We also explore two issues typically envisaged in the corporate governance (CG) literature, such as ownership structure and whether the auditor is one of the Big Four auditing firms (Big Four).

The informative content of these financial reports is a matter of major concern because capital markets are increasingly more demanding, and providing truthful, relevant information becomes crucial for markets' proper functioning, i.e., current and potential investors can properly evaluate their investments based on relevant information about companies' risk profile (Linsley \& Shrives, 2006).

Moreover, policy makers (Ley 31/2014) and academics (Ho \& Wang, 2008) posit that lack of transparency, excessive risk exposure, and weak governance structures have contributed to the growth of the financial crisis. Accounting scholars have identified a gap between actual and required information which contributed to increase volatility in the stock markets, since the accounting framework did not properly capture, measure and report the uncertainties and risks that companies were facing to allow stakeholders to adopt effective decisions (Magnan \& Markarian, 2011). The lack of proper risk disclosure helped to boost and amplify the current financial crisis (Kothari \& Lester, 2012), but this has changed to some extent.

To address these weaknesses, regulatory efforts have been made in Spain in recent years (Ley de Economía Sostenible 2/2011 or Ley 31/2014), fostering the implementation of additional good governance practices in order to enhance transparency, recover investors' trust, and raise the added-value generated by the companies, as stated by the Comisión Nacional del Mercado de Valores (CNMV) in 2015 through the Código Unificado de Buen Gobierno (Unified Good Governance Code [UGGC]). However, in our view, it remains a research question how these recommended good governance practices can prompt higher financial information transparency.

This paper builds on the CG literature that explores the impact of good governance mechanisms on the quality of financial information (Carcello \& Neal, 2003; Pomeroy \& Thornton, 2008; Pucheta-Martinez \& Fuentes, 2007; Pucheta-Martinez \& GarciaMeca, 2014) and risk disclosure (Cabedo \& Tirado, 2004, 2009; Deumes \& Knekel, 2008; Linsley \& Shrives, 2006; Oliveira, Rodrigues, \& Craig, 2011; Domínguez \& Gámez, 2014).

Our contribution to prior literature is twofold: Firstly, we apply fuzzy-set qualitative comparative analysis (fsQCA) a methodology that has recently been used in the context of CG issues (GarcíaCastro et al., 2013). The main advantage of the fsQCA method is that it explores combinatory effects among multiple CG practices, as well as the possible equifinality of different combinations in reaching the same outcome, and it captures the likely complexity of resulting combinations (Garcia-Castro et al., 2013). Traditional regressions follow an effects-of-causes approach in which the goal is to estimate if an individual variable has a significant (positive or negative) effect, net of other variables' effects, on the dependent variable in a population of cases. We used fsQCA instead, which mostly fits the causes-of-effects approach, to explore more complex pathways, i.e., combinations of necessary, sufficient and minimal conditions (Vis, 2012) related with good CG mechanisms under which high risk disclosure is provided in the CGAR. Hence, we found several causal recipes related with the outcome or response variable (Woodside, 2013). These factors do not determine an event, but can offer an evaluation of what is expected to be important for a given result to occur (Stevenson, 2013).

Secondly, we also explore how those recipes have evolved during the financial crisis, since archival literature provides an elusive conclusion about the impact of the crisis on risk disclosure: Probohudono, Tower, \& Rusmin (2013) failed to find a positive relationship between risk disclosure and the crisis in a sample of Asian companies.

For this purpose, we used a sample of financial and nonfinancial information related with listed companies for 2006 (a pre-crisis year), 2009 (a crisis year) and 2012 (an overcomingcrisis year). We used the risk disclosure index developed by Cabedo and Tirado (2009) and applied the fsQCA methodology.

Our results reveal that both for 2006 and 2012 there is a combination of good governance practices such as BoD's higher independence, size, level of activity, gender diversity, and CEO duality that drives high risk disclosure. Being audited by one of the Big Four is included in every recipe associated with high informative content on risk, thus becoming a necessary condition in 2009 and 2012. We found that ownership diversity, i.e. more than five significant shareholders, is neither sufficient nor necessary for high risk disclosure in any of the three years analyzed (in line with Rodriguez-Perez, 2004). Conversely, the presence of institutional investors is considered as a sufficient condition in every combination.

With regard to the configurations leading to the outcome high information content of risks, the configurations for 2009 differ significantly from those for 2006 and 2012; the number of required conditions for 2009 is generally lower compared to 2006 and 2012.

In all, our empirical findings support that there is no single path for enhancing financial information. There are companies 
with good governance structures that seem to increase the transparency of financial information, but the presence of institutional investors and a well-reputed auditor also lead to the same outcome. Hence, we conclude that good CG measures, although exhibiting different combinations, can foster higher quality reporting on the risk the company is facing. Therefore, our results could support recent regulatory efforts that foster good governance practices. The presence of institutional investors and being supervised by one of the international audit firms is also crucial for the outcome high risk disclosure in the CGAR.

\section{THE SPANISH REGULATORY FRAMEWORK OF RISK DISCLOSURE IN THE CORPORATE GOVERNANCE ANNUAL REPORT}

In 2006, the European Directive 2006/46/CE (Art. 7) established that listed companies should mandatorily include a CG assessment in their annual report, with the final aim of enhancing transparency and strengthening the role of the CG mechanisms.

However, this requirement had already been implemented in Spain: after the recommendations issued by the CNMV (Spanish Stock and Exchange Commission) in the Olivencia Code (1997) and Aldama Report (2003), public disclosure of the CGAR became mandatory in 2003, with the enactment of Ley $26 / 2003$. The CGAR content and structure were regulated through the Spanish Order released in 2003 (Orden ECO/3722/2003) and the Unified Good Governance Code of Listed Companies (UGGC) approved in 2006 (CNMV, 2006), thus covering our period of study.

Noteworthy, the core characteristics of the CGAR include: a) its voluntariness, i.e., the code adopts the "comply or explain" principle under which companies may voluntarily not follow its recommendations, although in this case they must explain such refusal; and b) binding definitions, i.e., companies can freely decide not to follow the code's Good Government recommendations, but their reporting must respect the underlying concepts used.

With regard to the issue under scrutiny, i.e. risk disclosure, the UGGC (2006) required the following specifications:

a. The different types of risk (operational, technological, financial, legal, reputational...) the company is exposed to, including financial or economic risks of contingent liabilities and other off-balance-sheet risks;

b. The risk level that the company deems acceptable;

c. Measures in place to mitigate the impact of risk events in case they occur; d. The internal reporting and control systems for controlling and managing the above risks, including contingent liabilities and off-balance-sheet risks. (UGGC, 2006; Recommendation no. 49)

In recent years, good examples of the efforts of policymakers to improve $\mathrm{CG}$ practices are the new requirements brought about by the Real Decreto (2010), the Ley de Economía Sostenible (2011) and the Ley 31/2014, which requires additional mandatory disclosure concerning the remuneration system of the board of directors and audit committee, among others. Additionally, the CGAR has been updated (Order ECC/461/2013) and revised (UGGC, 2015), but such relevant changes did not alter CGAR's information content regarding risk exposure nor do they lie within our period of analysis.

\section{LITERATURE REVIEW AND RESEARCH QUESTIONS}

Archival empirical studies on risk-informative content generally build on the literature about voluntary disclosure since this type of content is commonly issued under the "comply or explain" principle, as with the CGAR under scrutiny in this study. We identify voluntary disclosure as the quantity or quality of information that is reported beyond the minimum legal requirements (Barako, Hancock, \& Izan, 2006).

This strand of research builds from Agency Theory (Jensen \& Mekling, 1976), according to which the agent (manager) might decide to voluntarily provide information to the principal (shareholders), thus lessening problems of information asymmetry between the principal and the agent. Rodriguez-Perez (2004) explains that, within agency theory, this decision can be approached through different perspectives. Firstly, according to signal theory, choosing to issue voluntary information would signal the agent's attitude in favor of the principal, rather than a self-interested attitude (Giner, 1997). In the same vein, Gul and Leung (2004) and Deumes and Knechel (2008) confirm that the greater the agency problems, the more voluntary information is provided by the agent. Giner (1997) and Cabedo and Tirado (2009) found that companies with high profitability ratios are more likely to provide voluntary information in order to issue positive signals to the market. Gómez, Iñiguez, and Poveda (2006) also found that financial analysts recommend investing in companies that seem to be more transparent due to their supplying more voluntary information. Moreover, voluntary transparency drives less capital costs (Healy \& Palepu, 2001; Leuz \& Verrechia, 2000; Linsley \& Shrives, 2006) and less stock price spread (Healy \& Palepu, 2001) since creditors and investors will perceive the investment as less 
risky. In contrast, managers' avoidance of litigation risk, in case investors feel misled by actual figures turning up not as good as what was predicted in voluntary reports, can cause managers to refrain from releasing non-required information (Deumes \& Knechel, 2008). Hence, they might be reluctant to raise excessive awareness in stockholders about their performance, which could trigger higher attention and demands on the part of stakeholders.

Secondly, from the perspective of proprietary costs, reported information is not cost-free, and small and medium companies may be unable afford the issuance of voluntary disclosures. Additional concerns that may discourage voluntary disclosure involve the potential lack of profits or competitive advantage due to the use by competitors of the information voluntarily disclosed (Deumes \& Knechel, 2008; Broberg, Tagesson, \& Collin, 2010). Consequently, predicted cost-profit analyses drive voluntary disclosures with a poor quality of information (ICAEW, 2011).

The second strand of research on which we base the questions in our study deals with Good Government mechanisms.

According to Agency Theory, the Board of Directors (BoD) mitigates agency conflicts between the principal and the agent and lessens information asymmetry problems (Fama \& Jensen, 1983). Although some results do not corroborate this relationship, e.g., Barako et al. (2006), several empirical studies (Cabedo \& Tirado, 2009; Gul \& Leung, 2004; Oliveira et al., 2011; Domínguez-de la Concha \& Cauzo Bottala, 2015) and the meta-results reported by Garcia-Meca and Sanchez-Ballesta (2010) confirm that board independence is positively related with voluntary disclosure.

With regard to the effectiveness of the Audit Committee (AC) in monitoring financial reporting, meta-results from previous archival studies by Pomeroy and Thornton (2008) suggest that ACs are more effective in enhancing audit outcome (such as the issuance of a going-concern audit opinion) than in fostering some traditional measures of observed financial reporting quality (especially high quality accruals and avoiding restatements). Moreover, the higher the number of independent members in the $\mathrm{AC}$, the higher the number of restatements and abnormal accruals.

The size of the BoD provides different results. In Spain, the Code of Good Governance recommends BoDs to have between 5 and 15 members (Recommendation no. 9) to be efficient. However, Gisbert and Navallas (2009) failed to find a significant association with the level of voluntary disclosure. Conversely, Gul and Leung (2004) found a positive relationship with our variable of interest. Nevertheless, since BoD size is associated with company size, and this variable is positively associated with the level of disclosure, we expect an association between both variables.

The Olivencia Code (Recommendation no. 10) suggested that the BoD should meet regularly. Actually, Monterrey and
Sánchez (2008) found that BoD's level of activity is positively and significantly associated with earnings quality. Because we consider that risk transparency is also a measure of accounting quality, we predict a possible association between these two variables.

The separation of the roles of the Chairman and the Chief Executive Officer is a controversial issue (Manzaneque, Priego, \& Merino, 2016), i.e. under the monitoring hypothesis it may erodes the independence and effectiveness of the board (Fama \& Jensen, 1983) but the accumulation of powers of two figures in a single person (CEO duality) facilitates the transmission of information, reducing coordination costs and avoiding the emergence of potential conflict of interests between the two positions (Davis, Choorman, \& Donaldson, 1997). The duality of CEO and BoD president in the same person is not considered a good mechanism for the independence of the latter over the executive power. In the same vein, Gul and Leung (2004) corroborate that such duality is associated with lower levels of voluntary disclosure. Therefore, we expect to find an inverse relation between this duality and our variable of interest.

Finally, among other measures, the aim of the Ley $3 / 2007$ para la igualdad de mujeres y hombres 2007 is enhancing gender diversity in the BoD. To that end, the law requires, among others, that listed companies raise the proportion of women in BoDs to $40 \%$ by 2015 . The UGGC also states (Recommendation no. 15) for Boards of Appointments to implement mechanisms to promote the selection of women. Such gender diversity might enhance the quality of financial information, as well as voluntary disclosure.

In sum, we posit the following proposition:

Proposition 1: BoD's independence, size, activity level and gender diversity, CEO duality, and Audit Committee's independence are associated with high risk disclosure in the CGAR.

It is reasonable to expect that information asymmetry conflicts decrease when ownership concentration is higher. In the same vein, Deumes and Knechel (2008) and Broberg et al. (2010) found a negative relationship between ownership concentration and voluntary disclosure of information. Conversely, Barako et al. (2006) identify a significant but positive association.

In addition, Bushee and Noe (2000) found that institutional investors are more attracted by more informative firms. In our study, we explore the converse association. Therefore, we test the following proposition:

Proposition 2: Ownership dispersion and the presence of institutional investors are associated with high risk disclosure in the CGAR.

Giner (1997), Deumes and Knechel (2008) and Oliveira et al. (2011) found that financial statements supervised by the Big Auditing 
Firms offer more voluntary information than those audited by the remainder of public accounting firms. Hence, we propose as follows:

Proposition 3: Auditor quality is associated with high risk disclosure in the CGAR.

In sum, drawing on the findings of previous literature concerning these relationships, this study analyzes which sets of conditions explain more information content of risk factors in CGARs. We analyze every possible combination of conditions that can be drawn from the above propositions as causal sets rather than the individual impact of each single variable.

\section{METHODOLOGY AND RESULTS}

\section{Sample and research design}

We analyze a sample of Spanish non-financial listed companies for 2006 (pre-crisis period), 2009 (crisis period) and 2012 (overcomingcrisis period) with the final aim of examining whether the combinations of CG features that prompt high risk disclosure had evolved over this period. Data were hand-collected from the CGARs available at the official registration files of the CNMV and from financial statements recorded in the SABI database. All companies but the ones in the financial industry were selected. After dropping firms whose annual reports were not available or had incomplete information, the final data set consisted of 271 companies.

We consider risk exposure as the possibility that a company may suffer losses because of the interaction of several internal or external factors which are currently affecting the company, due to environmental uncertainty (Cabedo \& Tirado, 2004). Our variable of interest builds on Linsley and Shrives' (2006) concept that there is risk disclosure if the user has been informed about the opportunities or perspectives of any danger, damage, or uncertainty that could impact on the company or may affect the future or the management.

Following the ICAEW (1997) risk model, we identify two broad categories of risks: external risks, mainly related with environmental issues, and internal risks. Among the latter, we distinguish between financial risks, which directly affect monetary assets and liabilities, and non-financial risks. At the same time, within the financial risks subset, we employ the five financial risk categories disclosed in the International Financial Reporting Standard 7, i.e. exchange rate, credit, liquidity, commodities, and interest rate exposures. Within the non-financial risks subset, we identify information related to seven exposures, i.e., operational, business, strategic, regulatory compliance, information systems, integral risk, and others.
For the sake of comparability with prior results, we use the Cabedo and Tirado (2009) scoring, i.e., we distinguish five stages according to the level of informative content supplied by the company:

Stage 1: The company only mentions the risks it is exposed to.

Stage 2: The company describes the risks and how they affect the company.

Stage 3. The company reports a quantitative measurement of risk impact.

Stage 4 . The company reports on risk management.

Stage 5 . The company reports on the types of risk mitigation instruments it uses.

Every stage equals o if the required information is not disclosed and 1 otherwise. Therefore, the total risk index (TR) for each company $i$ is calculated by adding the scores of each (five financial and seven non-financial) type of risk. In sum, the total score for each company ranges from o to 60 (a maximum of 25 points for financial risks plus a maximum of 35 points for non-financial risks).

We apply fsQCA, which is built on the set-theoretic methods introduced by Ragin $(1987,2000,2008)$. The fsQCA tests whether a condition or combination of conditions is necessary and/or sufficient for a certain outcome. It also aims to reveal the minimal (combinations of) conditions bringing about a particular outcome (Vis, 2012), therefore, it explores complex pathways fsQCA essentially investigates set relations, and it changes variables within and across them to find the combinations of causal sets that better match the outcome. Sets are "fuzzy" when the criterion for membership allows objects to possess the required common property in varying degrees (Stevenson, 2013).

In our study, we explore complex combinations of conditions related to CG mechanisms and other financial and non-financial issues related to risk disclosure in the CGARs. In addition, thinking in terms of alternative mechanisms indicates that several causal recipes can relate to the outcome or response variable (Woodside, 2013). Besides, for studies with a moderately large-n, fsQCA has typically most to offer (Vis, 2012).

This type of study requires a decision about whether to use the parsimonious or the complex solution. The parsimonious approach takes all possible simplifying assumptions, that is, statements about the logical remainders or positions that did not happen in the sample. In contrast, the complex approach implies 
that no statements are being made about the situations that did not occur empirically. The latter is the approach used in this study.

\section{Outcome and conditions}

To apply fsQCA, we defined the outcome as the company's risk disclosure score. This score is estimated by applying the Cabedo and Tirado (2009) rating, which takes up a value ranging from o to 60 , according to the risk information included in the CGAR. We, then, tested the combinations of conditions that produce this outcome.

In order to explore the associations described above, we defined the following conditions in the raw form of continuous variables:

BDSIZE $=$ Number of BoD members

BDIND = Ratio of independent to total members in the BoD

BDGEN = Ratio of women to total members in the BoD

$\mathrm{BDACT}=$ Number of meetings per year

ACIND $=$ Ratio of independent to total members in the audit committee

We also employed conditions through variables with dichotomy values:

II = Presence of institutional investors, which equals 1 if there are institutional investors and o otherwise

$O D=$ Ownership dispersion, which equals 1 when there are more than five different significant shareholders (with significant shareholders being the owners of more than $5 \%$ of total shares)

CEOD $=$ CEO duality, which equals 1 if the BoD president and the CEO are different persons and o otherwise

$\mathrm{BIG}_{4}=$ Equals 1 if the company is audited by one of Big Auditing Firms and o otherwise

\section{Data calibration}

Calibration implies the transformation of data into fuzzy-sets, i.e. assigning a quantitative index from qualitative data (Stevenson, 2013), which represents a procedure analogous to performing a z-scale transformation of original data (Woodside, 2013). Transforming variables into a set requires the specification of three breakpoints: full membership to the set of interest (1), full nonmembership (o), and neither in nor out of the set (with the so-called crossover point at 0.5), using appropriate criteria (Ragin, 2008).

For our purposes, the outcome is high information content in CGAR, and the breakpoints $0,0.5$ and 1 are calculated using a percentile-based approach for the total risk. Continuous variables (conditions) are transformed into fuzzy-sets by using the same percentile-based approach. With a graphical representation of these variables using histograms and their quantiles, we set the fuzzy-set calibration breakpoints. For dummy variables, a value of one (1) indicates being fully in the set and a value of zero (0) fully out of it. Exhibit 1 displays the fuzzy-set calibration procedure for all conditions and outcomes.

\section{Exhibit 1. Calibration of outcome and conditions}

\begin{tabular}{|c|c|c|}
\hline Key & Condition/outcome & Calibration \\
\hline & & $\begin{array}{l}\text { Fuzzy-set calibration } \\
\text { breakpoints }\end{array}$ \\
\hline $\mathrm{TR}$ & $\begin{array}{l}\text { High information content of } \\
\text { total risks }\end{array}$ & $\begin{array}{l}\text { 3oth, 5oth and 8oth } \\
\text { percentiles }\end{array}$ \\
\hline BDIND & $\begin{array}{l}\text { Independent members ratio } \\
\text { in } B o D\end{array}$ & $\begin{array}{l}\text { 2oth, 5oth and 8oth } \\
\text { percentiles }\end{array}$ \\
\hline BDGEN & Women ratio in BoD & $\begin{array}{l}\text { 4oth, 6oth and 9oth } \\
\text { percentiles }\end{array}$ \\
\hline BDACT & $\begin{array}{l}\text { Number of annual BoD } \\
\text { meetings }\end{array}$ & $\begin{array}{l}\text { 2oth, 5oth and 8oth } \\
\text { percentiles }\end{array}$ \\
\hline ACIND & $\begin{array}{l}\text { Independent members ratio in } \\
\text { audit committee }\end{array}$ & $\begin{array}{l}\text { 2oth, 5oth and 8oth } \\
\text { percentiles }\end{array}$ \\
\hline \multirow[t]{2}{*}{ BDSIZE } & Total members in BoD & $\begin{array}{l}\text { 2oth, 5oth and 8oth } \\
\text { percentiles }\end{array}$ \\
\hline & & Crisp-set calibration \\
\hline II & $\begin{array}{l}\text { Institutional investors (dummy } \\
\text { variable that equals } 1 \text { if there } \\
\text { are institutional investors) }\end{array}$ & $\begin{array}{l}1 \text { indicates fully in } \\
\text { the set and o fully } \\
\text { out of it }\end{array}$ \\
\hline OD & $\begin{array}{l}\text { Ownership dispersion (dummy } \\
\text { variable that equals } 1 \text { when } \\
\text { there are more than } 5 \text { different } \\
\text { significant shareholders, with } \\
\text { significant shareholders being } \\
\text { the owners of more than } 5 \% \text { of } \\
\text { total shares) }\end{array}$ & $\begin{array}{l}1 \text { indicates fully in } \\
\text { the set and o fully } \\
\text { out of it }\end{array}$ \\
\hline CEOD & $\begin{array}{l}\text { CEO duality (dummy variable } \\
\text { that equals } 1 \text { if CEO and } \\
\text { Chairman of the BoD are } \\
\text { represented by different } \\
\text { individuals) }\end{array}$ & $\begin{array}{l}1 \text { indicates fully in } \\
\text { the set and o fully } \\
\text { out of it }\end{array}$ \\
\hline $\mathrm{BIG}_{4}$ & $\begin{array}{l}\text { Big Four accounting firms } \\
\text { (dummy variable that equals } 1 \text { if } \\
\text { the audit firm is Deloitte, KPMG, } \\
\text { PriceWaterhouseCoopers or } \\
\text { Ernst\&Young) }\end{array}$ & $\begin{array}{l}1 \text { indicates fully in } \\
\text { the set and o fully } \\
\text { out of it }\end{array}$ \\
\hline
\end{tabular}

Notes: TR refers to the outcome high risk information content disclosed in the CGAR. The other nine variables are the conditions.

In fsQCA, there are negated sets or the absence of a set, i.e., a condition that does not contribute to the outcome. In this study, we denote negated sets by writing their names in lowercase.

All models were fitted in R version 3.1.1 (R Core Team, 2014), and for fsQCA we used QCA package version 1.1-3 (Dusa \& Alrik, 2014). 


\section{Analysis of the conditions leading to high risk disclosure}

The final aim of fsQCA is to analyze set-theoretic sufficiency relations (Ragin, 2008). The sufficient condition set is a subset of the outcome set. It requires the construction of the truth table, which consists of all possible combinations of causal sets and shows which combinations of causal conditions produce the outcome. For $k$ causal sets, the truth table will have $2^{k}$ rows; because this study considers 10 conditions, the total number of possible combinations is $512\left(2^{9}\right)$.

We also test whether the conditions are necessary for the outcome by using the superSubset function of R package QCA. This function does not require a preselection of combinations to be tested, thus removing the risk of leaving potentially interesting results undiscovered (Dusa \& Alrik, 2013).

Similarly to the assessments of significance and strength in analyzing correlational connections, consistency and coverage are the two descriptive measurements used to assess fuzzyset relations (Hsu, Woodside, \& Marshall, 2013). With regard to sufficiency consistency, the key question is to what degree cases are members of the conditions and the outcome in relation to their overall membership in the conditions. In connection with sufficiency coverage, we investigate to what degree cases are members of the conditions and the outcome in relation to their overall membership in the outcome. Hence, if sufficiency consistency is high enough, the evidence is consistent with the hypothesis that the conditions are sufficient for the outcome (Dusa \& Alrik, 2013). Consistency scores are analogous to a Pearson's $r$ coefficient in statistical analysis; and coverage is analogous to the coefficient of determination, $r^{2}$, in statistical analysis (Hsu et al., 2013).

In a similar way to sufficiency, we estimate necessity consistency and necessity coverage. Results of sufficient conditions and their consistency and coverage indexes are shown in Table 1, while Table 2 presents data related with the necessary conditions.

Table 1. Analysis of sufficient conditions for the outcome high information content of total risk and for 2006, 2009 and 2012

\begin{tabular}{|c|c|c|c|c|c|c|c|c|}
\hline \multirow{2}{*}{ Configuration } & \multicolumn{3}{|c|}{ Year 2006} & \multicolumn{2}{|c|}{ Year 2009} & \multicolumn{3}{|c|}{ Year 2012} \\
\hline & 06_1 & $06 \_2$ & $06 \_3$ & 09_1 & $09 \_2$ & $12 \_1$ & $12 \_2$ & $12 \_3$ \\
\hline \multicolumn{9}{|l|}{ Condition } \\
\hline OD & (0) & (0) & (0) & - & (0) & (0) & (0) & (0) \\
\hline CEOD & (0) & (0) & (1) & (0) & (0) & - & (0) & \\
\hline BDGEN & (1) & (0) & 1 & (0) & (1) & (0) & (0) & (1) \\
\hline BDACT & (1) & (1) & 1 & (0) & (0) & (0) & (1) & (1) \\
\hline ACIND & (0) & 1 & 1 & (0) & (1) & (0) & 1 & (1) \\
\hline BDSIZE & (1) & 1 & & 1 & (0) & (1) & (0) & \\
\hline Coverage & 0.04 & 0.07 & 0.05 & 0.11 & 0.06 & 0.14 & 0.08 & 0.05 \\
\hline $\begin{array}{c}\text { Overall } \\
\text { consistency }\end{array}$ & 0.76 & & & 0.83 & & 0.88 & & \\
\hline $\begin{array}{c}\text { Overall } \\
\text { coverage }\end{array}$ & 0.16 & & & 0.16 & & 0.25 & & \\
\hline Sample size & 88 & & & 92 & & 91 & & \\
\hline Examples & $\begin{array}{c}\text { Cementos } \\
\text { Molins } \\
\text { Fomento de } \\
\text { construcciones } \\
\text { y contratas }\end{array}$ & $\begin{array}{c}\text { Enagas } \\
\text { Ence energía } \\
\text { Endesa }\end{array}$ & $\begin{array}{c}\text { Red eléctrica } \\
\text { Repsol } \\
\text { Tecnocom } \\
\text { Telecomunicaciones }\end{array}$ & $\begin{array}{c}\text { Grupo Tavex } \\
\text { Tubos } \\
\text { reunidos } \\
\text { Acerinox } \\
\text { Lingotes } \\
\text { Especiales } \\
\end{array}$ & $\begin{array}{c}\text { Industria de } \\
\text { diseño textil } \\
\text { Sotogrande }\end{array}$ & $\begin{array}{c}\text { Tubos reunidos } \\
\text { Vidrala } \\
\text { ACS } \\
\text { Actividades de } \\
\text { construccion y } \\
\text { servicios }\end{array}$ & \begin{tabular}{|c} 
Grupo \\
Ezentis \\
Sotogrande
\end{tabular} & $\begin{array}{c}\text { Red eléctrica } \\
\text { Repsol } \\
\text { Tecnocom } \\
\text { Telecomunicaciones }\end{array}$ \\
\hline
\end{tabular}

Notes: 1 Presence of the conditions in the model predicting the outcome (0) Absence or negation of the conditions.

- The conditions is irrelevant for information content (that particular antecedent is not figured in the model). Variables (conditions) are defined in Exhibit 1 
Table 2. Analysis of necessary conditions for the outcome high information content and for 2006, 2009 and 2012

\begin{tabular}{l|l|l}
\hline Year / Combination of conditions & Consistency & Coverage \\
\hline 1. High information content for 2006 & & \\
\hline $\begin{array}{l}\text { od + BDIND } \\
\text { ceod + BDSIZE }\end{array}$ & $\begin{array}{l}0.939 \\
0.902\end{array}$ & $\begin{array}{l}0.600 \\
0.611\end{array}$ \\
\hline $\begin{array}{l}\text { 2. High information content for } \\
2009\end{array}$ & & \\
\hline BIG4 & & \\
od + ceod & 0.952 & 0.606 \\
\hline 3. High information content for 2012 & 0.916 & 0.569 \\
\hline BIG4 & & \\
II & 0.919 & 0.619 \\
\hline
\end{tabular}

Note: Sample size is 88 for 2006, 92 for 2009 and 91 for 2012. Lower-case letters indicate the negation or absence of the condition. Variables (conditions) are defined in Exhibit 1.

The configurations in Table 1 are the different paths to achieving high risk disclosure. More than one combination of conditions is sufficient for achieving the outcome. Analyses for the intermediate and parsimonious solutions were not conducted in our work, which was limited to the available data without considering any counterfactuals. For each year, different combinations show a satisfying overall consistency (surrounding 0.80 ) and a reasonable overall coverage ( 0.16 for 2006 and 2009, going up to 0.25 for 2012).

For 2006, three combinations of conditions lead to a high level of information content of total risks. Solution 06_3 includes all the conditions but OD (companies with more than five significant shareholders). Red Eléctrica, Repsol and Tecnocom Telecomunicaciones are companies that have this configuration. Solution 06_2 is similar to the previous one, but it does not contain CEOD (CEO and president of BoD are not different persons in these companies) or BDGEN (low women ratio in BoD in these companies). Corporations such as Enagas, Ence Energía and Endesa fit in this recipe. Solution 06_1 excludes OD, CEOD, BDIND (independent members ratio in BoD is low) and ACIND (independent members ratio in audit committee is low). Cementos Molins and Fomento de Construcciones y Contratas are companies with this configuration.

According to the analysis of necessity (Table 2), there are two different combinations leading to high information content for 2006 (od + BDIND or ceod + BDSIZE) which are consistent with analysis of sufficiency.

There are two combinations of conditions that produce a high level of content of total risks for 2009. Solution 09_01 only requires the presence of three conditions: II (institutional investment), BIG4 (auditor belongs to one of the Big Four accounting firms) and BDSIZE (large number of members in BoD). Grupo Tavex, Tubos Reunidos, Acerinox and Lingotes especiales are companies that have this configuration. Interestingly, in Solution 09_02, half of the conditions are present while the other half are missing. Companies with this configuration are Industria de Diseño Textil and Sotogrande. Results of the necessity analysis (Table 3) show two alternative combinations (BIG4 or od + ceod) and these two configurations are in accordance with the analysis of sufficiency.

For 2012, two combinations of conditions lead to a high level of content of total risks. Solution 12 _3 is identical to Solution 06 3 and companies in both solutions coincide to a great extent. Solution 12_2 is much the same as Solution 06_2. Grupo Ezentis and Sotogrande are companies that have this configuration. And Solution 12_1 only exhibits the inclusion of three conditions: II, BIG4 and BDSIZE. Companies with this combination are Tubos Reunidos, Vidrala, and Actividades de Construcción y Servicios. With regard to the analysis of necessity, $\mathrm{BIG}_{4}$ or II are two individual conditions that would be necessary to obtain the outcome.

As shown in Table 1, the configurations leading to the outcome high information content of risk for 2009 (one of the years of the recent economic crisis) are quite different from the configurations for 2006 (pre-crisis year) and 2012 (overcomingcrisis year). The third combination of conditions for 2006 and 2012 is identical, and the second is very similar. Likewise, the number of required conditions for 2009 is generally lower compared to 2006 and 2012. It is particularly noteworthy that BDACT is not present in any of the 2009 configurations, which could be attributed to a low activity of BoD. Condition CEOD is also not included in any of the 2009 recipes, indicating that $C E O$ and $B O D$ president are not different persons. On the other hand, II and BIG4 are two conditions included in all of the sufficiency combinations we found, regardless of the year. BDSIZE, BDIND and ACIND are present in the majority of the eight recipes. $O D$ is not present in any of them, meaning an ownership dispersion with more than 5 different significant shareholders.

In addition, Dusa and Alrik (2013) point out that seemingly paradoxical relations can appear in fsQCA in the sense that an important amount of cases can confirm a situation in which a condition is considered sufficient both for an outcome and for its negation. Therefore, in Table 3, as a robustness test, minimization was conducted for the negation of the outcome high information content for the three years. None of the combinations we found in the three years show a consistency score for outcome negation that was high enough to confirm a paradoxical relationship. 
Table 3. Analysis of sufficient conditions for the negation of the outcome high information content in 2006, 2009 and 2012

\begin{tabular}{c|c|c}
\hline Combination & Consistency & Coverage \\
\hline $06 \_1$ & 0.583 & 0.032 \\
\hline $06 \_2$ & 0.546 & 0.056 \\
\hline $06 \_3$ & 0.697 & 0.059 \\
\hline 09_1 & & \\
\hline 09_2 & 0.686 & 0.107 \\
\hline 12_1 & 0.478 & 0.023 \\
\hline $12 \_2$ & & 0.114 \\
\hline $12 \_3$ & 0.565 & 0.057 \\
\hline
\end{tabular}

We conducted further robustness tests because another source of problems could arise from a sufficiency relation between a condition and the outcome, particularly when there is strong evidence for the existence of a sufficiency relation between the negation of the conditions or the prime implicants identified as sufficient and the outcome (Dusa \& Alrik, 2013). Table 4 shows that the consistency scores for the negation of the identified combination of conditions for the three years are low enough to confirm this contradiction. Finally, we performed additional robustness tests (not reported) regarding the analysis of a) the negation of the necessary conditions for the outcome and $b$ ) the necessary conditions for the negation of the outcome.

Table 4. Analysis of sufficient conditions for the negation of the conditions in 2006, 2009 and 2012

\begin{tabular}{c|c|c}
\hline Combination & Consistency & Coverage \\
\hline $06 \_1$ & 0.559 & 0.000 \\
\hline $06 \_2$ & 0.560 & 0.000 \\
\hline $06 \_3$ & 0.565 & 0.000 \\
\hline 09_1 & 0.589 & 0.034 \\
\hline 09_2 & 0.569 & 0.043 \\
\hline 12_1 & 0.592 & 0.000 \\
\hline 12_2 & 0.581 & 0.003 \\
\hline $12 \_3$ & 0.581 & 0.008 \\
\hline
\end{tabular}

In sum, results show that the outcome high information content of risks may result from several different combinations of conditions and, in this respect, there are certain differences between 2006, 2009 and 2012. The confirmation of Propositions 1 to 3 dealing with the influence of conditions on the outcome reveal, to a greater or lesser extent, that BoD characteristics (independence, size, activity, duality, and gender diversity), independence of Audit Committee, ownership structure, and auditors quality are associated with high risk disclosure in the CGAR. Additionally, companies that shared a configuration tend to belong to the same sector.

\section{CONCLUSIONS}

This paper contributes to the existing literature that links CG mechanisms and financial reporting quality by examining the conditions under which the CGAR displays high informative risk disclosure. Our findings show that, in predicting high information content, different paths can lead to the same outcome.

The present paper builds on set-theoretic methods to describe complex pathways that can lead a company to produce a CGAR with high information content regarding risks. Our findings include new complex ways to approach conditions for an increase in CGAR quality, which shows support for causal asymmetry. Several causal recipes are related to the outcome or response variable.

High information content about the sample firms' risks in their CGAR for 2006, 2009 and 2012 are the three outcomes of interest in our study. We found a few differences in the composition of the condition recipes influencing information content for the three years. For 2009 (a year in the recent economic crisis), the configurations leading to the outcome high information content of risks are quite different from the configurations for 2006 (a pre-crisis year) and 2012 (a post-crisis year). Most combinations of conditions for 2006 and 2012 are very similar. The number of required conditions for 2009 is generally lower compared to 2006 and 2012. All configurations displayed for year 2009 show a low level of BoD activity and absence of CEO duality (CEO and Chairman of the BoD are in charge of the same people). Likewise, the presence of institutional investors and being audited by one of the Big Auditing Firms are two conditions included in every sufficiency combination found, regardless of the year. In addition, all paths for the three years studied have in common an ownership dispersion of less than 5 different significant shareholders.

On the other hand, the confirmation of all propositions dealing with the influence of the conditions on the outcome reveal to a greater or lesser extent that BoD characteristics (independence, size, activity, duality, and gender diversity), independence of Audit Committee, ownership structure, and auditors quality are associated with high risk disclosure in the CGAR. Additionally, we found that the multiple configurations or 
solutions seem to be related to the fact that most companies in a given configuration belong to the same sector.

Furthermore, none of these conditions by itself leads to the outcome; each of them is included in a prime implicant or combination of conditions which produces the outcome. These identified factors do not determine high information content, but offer an assessment of what is expected to be important to obtain a CGAR with high information content about risk exposures. Results are robust to several forms of analysis.

Among other limitations, our sample of study includes only listed companies. Expanding the sample with non-listed companies or adopting and international scope would enrich our findinds.

\section{REFERENCES}

Barako, G., Hancock, P., \& Izan, H. Y. (2006). Factors influencing voluntary corporate disclosure by Kenyan companies. Corporate Governance, 14(2), 107-125. doi:10.1111/j.1467-8683.2006.00491.x

Broberg P., Tagesson T., \& Collin, S. (2010). What explains variation in voluntary disclosure? A study of the annual reports of corporations listed on the Stockholm Stock Exchange. Journal of Management \& Governance, 14(4)351-377. doi:10.1007/s10997-009-9104-y

Bushee, J., \& Noe, C. (2000). Corporate disclosure practices, institutional investors, and stock return volatility. Journal of Accounting Research, 38(2000), 171-202. doi:10.2307/2672914

Cabedo, J. D., \& Tirado, J. M. (2004). The disclosure or risk in financial statements. Accounting Forum, 28(2), 181-200. doi:10.1016/j. accfor.2003.10.002

Cabedo, J. D., \& Tirado, J. M. (2009). Divulgación de información sobre riesgos: Una propuesta para su medición. Innovar, 19(34), 121-134.

Carcello, J. V., \& Neal, T. N. (2003). Audit committee independence and disclosure: Choice for financially distressed firms. Corporate Governance: An international Review, 11(4), 289-299. doi:10.1111/1467-8683.00327

Comisión Nacional del Mercado de Valores. (1998). Comisión especial para el estudio de un código ético de los consejos de administración de las sociedades. Código Olivencia. Spain.

Comisión Nacional del Mercado de Valores. (2003). Informe de la comisión especial para el fomento de la transparencia y seguridad en los mercados y en las sociedades cotizadas. Informe Aldama. Spain.

Comisión Nacional del Mercado de Valores. (2006). Código unificado de buen gobierno de las sociedades cotizadas. Spain.

Comisión Nacional del Mercado de Valores (2015). Código unificado de buen gobierno de las sociedades cotizadas. Spain

Davis, J., Choorman, F., \& Donaldson, I. (1997). Toward a stewardship theory of management. Academy of Management Review 22(1), 20-47.

Deumes, R., \& Knechel, W. R. (2008). Economic incentives for voluntary reporting on internal risk management and control systems. Auditing: A Journal of Practice and Theory, 27(1), 35-66. doi:10.2308/ aud.2008.27.1.35
Directive 2006/46/EC of the European Parliament and of the Council of 14 June 2006 amending Council Directives 78/660/EEC on the annual accounts of certain types of companies, 83/349/EEC on consolidated accounts, 86/635/EEC on the annual accounts and consolidated accounts of banks and other financial institutions and $91 / 674 / E E C$ on the annual accounts and consolidated accounts of insurance undertakings

Domínguez, L. R., \& Gámez, L. C. N. (2014). Corporate reporting on risks: Evidence from Spanish companies. Revista de Contabilidad-Spanish Accounting Review, 17(2), 116-129. doi:10.1016/j.rcsar.2013.10.002

Dusa, A., \& Alrik, T. (2013). Qualitative comparative analysis with $R$. New York, USA: Springer.

Dusa, A., \& Alrik, T. (2014). QCA: A package for qualitative comparative analysis. $\mathrm{R}$ package version 1.1-3. Retrieved from http://CRAN.Rproject.org $/$ package $=Q C A$

Domínguez-de la Concha Castañeda, M., \& Cauzo-Bottala, L. (2015). Consequences of CEO change: Long term effects on top management team and firm performance. Revista Española de Financiación y Contabilidad, 44(1), 72-96. doi:10.1080/02102412.2014.987447

Fama, E. F., \& Jensen, M. C. (1983). Separation of ownership and control. Journal of Law and Economics, 26(2), 301-325.

García-Castro, R., Aguilera, R. V., \& Ariño, M.A. (2013). Bundles of firm corporate governance practices: A fuzzy set analysis. Corporate Governance: An International Review, 21(4), 390-407. doi:10.1111/ corg.12024

García-Meca, E., \& Sanchez-Ballesta, J. P. (2010). The association of board independence and ownership concentration with voluntary disclosure: A meta-analysis. European Accounting Review, 19(3), 603-627. doi:10.1080/09638180.2010.496979

Giner, B. (1997). The influence of company characteristics and accounting regulation on information disclosed by Spanish firms. The European Accounting Review, 6(1), 45-68. doi:10.1080/096381897336863

Gómez, J. C., Iñiguez, R., \& Poveda, F. (2006). Revelación voluntaria de información y características de las sociedades cotizadas en el mercado de capitales español. Revista Española de Financiación y Contabilidad, 131, 8-32.

Gul, F., \& Leung, S. (2004). Board leadership, outside director's expertise and voluntary corporate disclosures. Journal of Accounting and Public Policy, 23(5), 351-379. doi:10.1016/j.jaccpubpol.2004.07.001

Healy, P., \& Palepu, K. (2001). Information asymmetry, corporate disclosure, and the capital markets: A review of the empirical disclosure literature. Journal of Accounting and Economics, 31(1-3), 405-440. doi:10.1016/S0165-4101(01)00018-0

Ho, W.-R., \& Wang, Y.-C. (2008). The relationship between corporate governance and financial crisis. Journal of Accounting, Finance and Management Strategy, 4(1), 63-84.

Hsu, S., Woodside, A., \& Marshall, R. (2013). Critical tests of multiple theories of cultures' consequences. Journal of Travel Research, 52(6), 679-704. doi:10.1177/0047287512475218

Institute of Chatered Accountants in England and Wales. (1997). Financial reporting of risk: Proposals for a statement of business risk. London, UK: ICAEW.

Institute of Chatered Accountants in England and Wales. (2011). Reporting business risks: Meeting expectations. London, UK.

International Accounting Standards Board (2014). International Financial Reporting Standard 7 Financial Instruments: Disclosures. London, UK. 
Järvinen, J., Lamberg, J., Murmann, J., \& Ojala, J. (2009). Alternative paths to competitive advantage: A fuzzy-set analysis of the origins of large firms. Industry and Innovation, 16(6), 545-574. doi:10.1080/13662710903371066

Jensen, M. C., \& Meckling, W. H. (1976). Theory of the firm: Managerial behavior, agency costs and ownership structure. Journal of Financial Economics, 3(4), 305-360. doi:10.1016/0304-405X(76)90026-X

Kothari, S. P., \& Lester, R. (2012). The role of accounting in the financial crisis: Lessons for the future. Accounting Horizons, 26(2), 335-351. doi:10.2308/acch-50134

Leuz, C., \& Verrecchia, R. E. (2000). The economic consequences of increased disclosure. Journal of Accounting Research, 38(Suppl.), 91-124. doi:10.2307/2672910

Ley 24/1988, 28 de July, del Mercado de Valores. Artículo 116 se modificó por la Ley $2 / 2011$ y por el R. D. Legislativo $1 / 2010$ que aprueba el texto refundido de la Ley de Sociedades de Capital vigente que contempla el IAGC.

Ley $26 / 2003$, de 17 de julio, por la que se modifican la Ley $24 / 1988$, de 28 de julio, del Mercado de Valores, y el texto refundido de la Ley de Sociedades Anónimas, aprobado por el Real Decreto Legislativo $1564 / 1989$, de 22 de diciembre, con el fin de reforzar la transparencia de las sociedades anónimas cotizadas.

Ley Orgánica 3/2007, 22 de March 2007, para la Igualdad Efectiva de Mujeres y Hombres. (2007). BOE no 71, 23/3/2007.

Ley 2/2011, de 4 de marzo, de Economía Sostenible.

Ley $31 / 2014$, de 3 de diciembre, por la que se modifica la Ley de sociedades de capital, para la mejora del gobierno corporativo

Linsley, P. M., \& Shrives, P. J. (2006). Risk reporting: A study of risk disclosures in the annual reports of UK companies. The British Accounting Review, 38(4), 387-404. doi:10.1016/j.bar.2006.05.002

Magnan, M., \& Markarian, G. (2011). Accounting, governance and the crisis: Is risk the missing link? European Accounting Review, 20(2), 215-231. doi:10.1080/09638180.2011.580943

Manzaneque, M., Priego, A. M., \& Merino, E. (2016). Corporate governance effect on financial distress likelihood: Evidence from Spain. Spanish Accounting Review, 19(1), 111-121. doi:10.1016/j. rcsar.2015.04.001

Monterrey, J., \& Sánchez, M. A. (2008). Gobierno corporativo y calidad de la información contable: Evidencia empírica española. Revista de Contabilidad, 11(1), 67-100.

Oliveira, J., Rodrigues, L., \& Craig, R. (2011). Risk-related disclosures by non-finance companies: Portuguese practices and disclosure characteristics. Managerial Auditing Journal, 26(9), 817-839. doi:10.1108/02686901111171466

Orden ECO/3722/2003, 26 December 2003. (2003). Sobre el IAGC y otros instrumentos de información de las sociedades anónimas cotizadas y otras entidades.
Pomeroy, B., \& Thornton, D. B. (2008). Meta-analysis and the accounting literature: The case of audit committee independence and financial reporting quality. European Accounting Review, 17(2), 305-330. doi:10.1080/09638180701819832

Probohudono, A. N., Tower, G., \& Rusmin, R. (2013). Risk disclosure during the global financial crisis. Social Responsibility Journal, 9(1), 124-137. doi:10.1108/17471111311307859

Pucheta-Martinez, M. C., \& Fuentes, C. de. (2007). The impact of audit committee characteristics on the enhancement of the quality of financial reporting: An empirical study in the Spanish context. Corporate Governance: An International Review, 15(6), 1394-1412. doi:10.1111/j.1467-8683.2007.00653.x

$\mathrm{R}$ Core Team. (2014). R: A language and environment for statistical computing. R Foundation for Statistical Computing, Vienna, Austria. Retrieved from http://www.R-project.org

Ragin, C. C. (1987). The comparative method: Moving beyond qualitative and quantitative strategies. Berkeley, USA: University of California Press.

Ragin, C. C. (2000). Fuzzy set social science. Chicago, USA: University of Chicago Press.

Ragin, C. C. (2008). Redesigning social inquiry: Fuzzy sets and beyond. Chicago, USA: University of Chicago Press.

Real Decreto Legislativo 1/2010, de 2 de julio, por el que se aprueba el texto refundido de la Ley de Sociedades de Capital.

Rodriguez-Perez, G. (2004). Factores explicativos de la revelación voluntaria de información sobre fuentes de ventaja competitiva empresarial. Revista Española de Financiación y Contabilidad, 33(122), 705-739.

Ruiz, I., Laffarga, J., \& Jiménez, S. M. (2001). Características de la información revelada sobre riesgos en España. Actualidad Financiera, $6(4), 29-48$.

Stevenson, I. (2013). Does technology have an impact on learning? A fuzzy set analysis of historical data on the role of digital repertoires in shaping the outcomes of classroom pedagogy. Computers \& Education, 69, 148-158. doi:10.1016/j.compedu.2013.07.010

Vis, B. (2012). The comparative advantages of fsQCA and regression analysis for moderately large- $\mathrm{N}$ analyses. Sociological Methods \& Research, 41(1), 168-198. doi:10.1177/0049124112442142

Woodside, A. (2013). Moving beyond multiple regression analysis to algorithms: Calling for adoption of a paradigm shift from symmetric to asymmetric thinking in data analysis and crafting theory. Journal of Business Research, 66(4), 463-472. doi:10.1016/j. jbusres.2012.12.021 